\title{
FIELD DAY AT PROPEKAY OF MR C. F. SHUTTLEWORTH, 88 VALLEY, WAKEFIELD
}

\section{MR SHUTTLEWORTH}

The area of the Moutere gravels amounts to 300,000 to 400,000 acres. Where it was grazeable it carried about one ewe to four acres in its natural state, running them badly at that with about 4 lb. of wool.

We started operations on this property just over three years ago, We were anxious to get grass to grow where there was scrub and manuka before. The scientists can tell us pretty readily the requirements in manures. The plant breeders have made available good strains of pasture plants. We rely on God for the moisture and on the bankers for finance, and we have found the bankers more unwilling than God.

We have given up the swamp plough and are relying on discing. We apply up to two tons of lime per acre with the grass sowing and 3 to 5cwt. of. superphosphate. The seeds mixture is: 1 to $1 \frac{1}{2}$ bushels of perennial ryegrass, $51 \mathrm{~b}$. of short-rotation ryegrass, a bit of cocksfoot and dogstail, and 6 to 8lb. of clovers (white, subterranean, and red).

Our problems are slope and erosion. The technique is to tell the tractor driver: "That's impossible; better keep off." Then get to hell out; it nearly always gets done !

We are keen on ryecorn; it helps to hold the soil within a week or two. It works in very well, as we can put a number of sheep on it, take them off, and it recovers very rapidly. It is also better than a root crop in that it never leaves the ground bare.

A disadvantage with sowing straight from discing is that the number of gorse seedlings striking is high and they are hard to get rid of. There is no doubt that with the swamp plough you do get rid of gorse. I don't think with discing you can get rid of gorse if the area is sown straight in. If there is no 
gorse, then it would'be foolish not to put it straight into grass, as there must be some fertility there that the grass might just as well have as the ryecorn.

\section{R. WILKIE (on contoured paddock)}

This paddock when originally worked up rilled badly after heavy rain. It was then contoured and sown broadcast in the general line of the furrows. The strike and growth are due to the fact that it was sown in line with the furrow to make available the maximum moisture. Furrows were spaced at $8 \mathrm{ft}$. vertical intervals.

Furrowing was done with the grader and plough. Half the expenditure was on the survey and half in putting the job in. Pasture furrows cost $3 \mathrm{~s}$. to $4 \mathrm{~s}$. per acre. Originally we used level absorption banks and they were quite successful. In some areas, though, level banks are inclined to fill up and scour. Graded banks have such a slight slope that excess rain will drain off. In normal circumstances they will absorb all the moisture available.

\section{M. E. MERRY}

This country was extremely sour. It was covered in beech forest. After the bush was felled and burnt it was sown in English grasses, which went out very early and native species took over. This effort of Mr Shuttleworth's is really the second attempt at bringing the country in.

The $\mathrm{pH}$ of untreated soil is 5.1 to 5.3. Calcium, potash, and phosphate levels are extremely low. The country was completely devoid of clovers.

In the early years the Cawthron Institute established a number of trials. Stock did very poorly ; bone structure was light, the wool poor, and there was high mortality.

The two essentials, lime and phosphate, plus good seed, did miracles.

In the past 16 or 1 '7 years a large number of manurial and strains trials have been carried out in this country. It became fairly apparent that if phosphate only "was used the results were very poor. Liming of high-grade lime at 1 ton per acre is insufficient. More than that is needed to get successful pastures. The most successful plot had 2 tons of lime and 3cwt. of phosphate per acre. Molybdenum at $2 \frac{1}{2} \mathrm{oz}$ per acre 
is giving very good results, particularly where liming has not been at heavy rates. Lime and superphosphate and molybdenum will work miracles.

Perhaps in the past in breaking in this country too light dressings have been used. It seems to need massive applications. If clovers do not strike, ryegrass will go out quickly and browntop and native species come in.

The copper status is low too. In time to come it might be advisable to use copper too. It is essential to use borax in association with lime and superphosphate if a swede or turnip crop is being taken.

\section{R. H. SCOTT}

Although one or two farmers in the Nelson district had land topdressed and oversown from the air two or three years ago, aerial topdressing is really only in its infancy in the district. Last autumn approximately 350 tons of superphosphate were spread by aircraft in the Nelson and Golden Bay districts and it is expected that about twice this tonnage will be spread next autumn.

When you look about you from here and see 'practically nothing but hill country, there certainly appears to be scope for aerial topdressing. You possibly remember in a paper on the first evening of the conference you were told that no more than 3 per cent. 'of the land surface of the four counties is flat; the remainder is hilly and mountainous, but of course much of it cannot be used for farming.

A tentative estimate which I have prepared shows that there is possibly about 100,000 acres of farmable hill country if it was all cleared which would benefit from aerial topdressing and oversowing. There are the eastern hills before us, parts of the Moutere Hills, some hill areas about the Takaka Valley, and some lower hill slopes in the Tutaki, Matakitaki, and Shenandoah Valleys in the Murchison district.

However, to do the job is costly. For instance, by the time superphosphate is landed on farms in this area it costs approximately $£ 15$ a ton, and the total cost to get 2cwt. of superphosphate spread per acre would be about £2 2 s., this covering the cost of fertiliser, labour provided by the farmer to assist in loading the aircraft, aircraft spreading costs, and any . interest on capital invested in an airstrip or airstrip fee. 
In the Golden Bay district the cost is higher, for there superphosphate costs between $\$ 16$ and $£ 17$ per ton by the time it is landed at the farmer's gate. The all-in cost of getting 2cwt. per acre spread by aircraft would be approximately $£ 24 \mathrm{~s}$. to $£ 26 \mathrm{~s}$.

These costs are higher than for most North Island districts, where $£ 118 \mathrm{~s}$. per acre is fairly high.

However, in spite of these costs there are farmers in Nelson and Golden Bay who consider aerial top-dressing and oversowing is well. worth while.

\section{R. T. C. RAINE}

The great problem in this country is when it wants not only superphosphate but heavy dressings of lime. The cost of applying lime from the aeroplane puts it completely out. On my farm I have to put either a big dressing of lime every 2 or 3 years or smaller amounts annually. I prefer now to give 5cwt. of lime annually and a bag of superphosphate.

There is quite a big area here as in other parts of New Zealand where you cannot take the topdresser. The answer is the blower, It is sometimes thought that the wind is of great assistance in the use of the blower. My opinion is that it is better if there is no wind. On a calm day you can throw the material about a chain. With a crawler tractor you can take the machine, out to the country and do about 30 acres a day. We find that by using a bulldozer to put in roads-they are in fact only level areas-the use of the blower is assisted tremendously.

After ploughing the gorse you get gorse showing up again for years after. Spraying with $245 \mathrm{~T}$ is effective and roads constructed for the use of the blower are also useful for gorse spraying. There is no doubt a place for the blower between the orthodox wheels and the aeroplane. You can sow seed with it too. The blower topdresser is a relatively simple and effective means of topdressing on country you can't get on to with the ordinary topdresser.

\section{C. LEITCH}

On country of this type where you want to get the clovers you need to watch the amount of shortrotation and perennial ryegrass in the mixture. They become aggressive to the exclusion of the clovers. In these dry conditions this is to some extent evident, though where there is 'moisture the clover is holding 
its own. The practical application of general mixtures to particular conditions is very important. At this stage the cocksfoot that was included in the mixture should be showing up. If you get very quick establishment of ryegrass at fairly heavy rates, the chances are that the clovers are going to have a struggle. Subterranean clover is the pioneer so far as establishment and building up of the nitrogen supply is concerned. I would certainly approve the inclusion of up to 21b. per acre. Starting with low fertility, one thing subterranean clover needs is phosphate. If the subterranean clover is inclined to disappear there is nothing wrong with that so long as other clovers are taking its place.

Seed mixtures on this class of country should err on the side of greater quantities of clover and less of ryegrasses. I would be inclined to cut the. normal $251 \mathrm{~b}$. of ryegrasses back to $151 \mathrm{~b}$. If the pasture opens up, other things will come in, it may be true, but if you are applying the fertiliser and lime required, then the ingress of other things is not worth worrying about. If you are getting clovers-and aggressive types-then you will get fertility and the results you want.

\section{P. H. McGLOIN}

The first problem in this country was the initial establishment of grass; then careful grazing to allow the white clover to tiller.

The carrying capacity in December is $4 \frac{1}{2}$ to 5 ewes per acre, or' even more, on pasture 2 years old.

The success of grass management was due to lenient grazing in the second year.

\section{F. E. T. SUCKLING}

To get an idea of the results from the surface sowing of clovers a series of trials have been established round the Moutere gravels and principles as in areas of the North Island applied. Clovers have struck where there is enough moisture. The plots have shown that provided lime, potash, and phosphate are applied in ample quantities you will get results. We have been trying to show results with small quantities of lime plus molybdenum. Other trials in the district, and also in the North Island, show this is possible. 
On country that is discable, the first job is to disc, but where it is too steep oversowing can and should be tried.

\section{J. P. FOX}

The use of molybdenum shows great promise. The soils are naturally very infertile, and the fact that they are being brought in reflects great credit on the farmers concerned.

\section{PROFESSOR A. W. HUDSON}

We have witnessed on Mr Shuttleworth's property the application in practice of what science has shown. The same thing is going on from North Cape to the Bluff. But whether it is in the north or the south the , same principle is being applied with modifications. It is development made possible by the work of science. 